\title{
A rapid spectrophotometric method for the determina- tion of bromine in seawater and in the ash of marine algae
}

\author{
P. SAENGer \\ Department of Botany and Microbiology, Rhodes University; \\ Grabamstown, South Africa
}

KURZFASSUNG: Eine spektrophotometrische Schnellmethode zur Bestimmung von Brom in Meerwasser und in der Asche mariner Algen. Zur quantitativen Bestimmung von Brom in organischen Substanzen bei Anwesenheit anderer Halogene wird eine einfache spektrophotometrische Methode beschrieben. Bei $400 \mathrm{~nm}$ ist die Absorption in Chloroform der Bromkonzentration im Bereich zwischen 0 und $0,6 \mathrm{~g} / 1$ proportional. Als Beispiele werden Bestimmungen des Br-Gehalts in Seewasser und in der Asche verschiedener mariner Rhodophyceen mitgeteilt.

\section{INTRODUCTION}

Since the discovery of bromine in seawater (BALARD 1826), a number of techniques for the quantitative estimation of this element in organic matter have been developed. These methods involve the liberation of bromine from its bromides with a simultaneous colour change in some suitable compound added to the solution, e.g. fuchsin (INDovina 1935), strychnine and persulphate (BINKLEY 1948), fluorescein (BERKOVICH \& LUzINA 1950) and rosaniline (HunTER \& Goldspink 1954). Other methods require the removal of other halogens prior to the liberation of bromine and its subsequent titration with sodium thiosulphate (Pincussen \& Roman 1935, Shirahama et al. 1944).

SEGI \& TAKATORI (1952) described a method for the colourimetric determination of bromine in marine algae, where the solutions obtained after ashing, are acidified with dilute sulphuric acid and a small volume of chlorine water, causing the liberation of molecular iodine. Subsequently a larger amount of chlorine water is added and colourless iodic acid is formed, the solution again becoming colourless as a result. Further addition of chlorine water liberates bromine which is shifted into chloroform and determined using a Dubosq colourimeter.

As the absorbance spectra in chloroform of bromine and iodine do not overlap significantly, liberated bromine can be readily determined using a spectrophotometer without the serial additions of chlorine water. A rapid, accurate modification of the method of SEGI \& TAKATORI (1952) for the determination of bromine in the presence of other halogens is described. 


\section{MATERIAL AND METHODS}

Preparation of standard solutions: Solutions of known bromine concentrations were prepared using analytical reagent grade $\mathrm{KBr}$. Reaction mixtures consisted of $20.0 \mathrm{ml} \mathrm{KBr}$ solution, $5.0 \mathrm{ml} \mathrm{H}_{2} \mathrm{SO}_{4}(16 \mathrm{~N}), 5.0 \mathrm{ml}$ chloroform and $1.5 \mathrm{ml}$ chloramine $\mathrm{T}(15 \mathrm{~g} / 1)$. This mixture was shaken vigourously and the chloroform phase, upon separation, was used for spectrophotometric analysis.

S p e ctroscopy : All spectroscopy was carried out with a Beckman SP 800 spectrophotometer using $1 \mathrm{~cm}$ silica glass cuvettes. Chloroform was used to zero the instrument. The Br-containing chloroform solution was then inserted and an absorbance spectrum run from $700-350 \mathrm{~nm}$. Absorbances were read at 400 and $650 \mathrm{~nm}$. Absorbance at $650 \mathrm{~nm}$ was used to allow for slight differences in the turbidity of the samples and was subtracted from the absorbance at $400 \mathrm{~nm}$. If absorbance at $400 \mathrm{~nm}$ exceeded 1.5 , the original $\mathrm{KBr}$ solution was diluted correspondingly.

Preparation of seawater and algal ash samples: Seawater samples were collected in small, tightly-sealing MCCARTNEY flasks and centrifuged in these flasks at $3000 \mathrm{rpm}$ for 45 minutes to remove suspended material. Subsequent procedure as for the $\mathrm{KBr}$ solutions. Algal material was freshly collected, cleaned of sand and epiphytes, briefly rinsed twice in distilled water and oven-dried at $65^{\circ} \mathrm{C}$ for 24 hours. A dried algal powder was produced by grinding in a Casella Grainmill (0.12" mesh size sieve) and the powder dried for a further 4 hours at the same temperature. Small amounts (generally $1-3 \mathrm{~g}$ ) of the powder were weighed into silica dishes and $10.0 \mathrm{ml}$ of $10 \% \mathrm{Na}_{2} \mathrm{CO}_{3}$ added to prevent volatilization of bromine. Ashing took place in a Gallenkamp muffle furnace at $400-440^{\circ} \mathrm{C}$ for 8 hours. After cooling, small quantities of distilled water were added and the dishes warmed over a water bath. The contents were then filtered using Whatman No. 541 paper and washed repeatedly with cold distilled water and finally made up to volume (generally $100 \mathrm{ml}$ ). These solutions were then treated like the $\mathrm{KBr}$ solutions.

\section{RESULTS}

\section{Calibration curve}

The relationship between the concentration of the standard $\mathrm{KBr}$ solutions, the calculated $\mathrm{Br}$ concentration and the measured absorbance is given in Table 1. Plotting of these values showed that the relationship between $\mathrm{Br}$ concentration and absorbance is not strictly linear, deviating slightly at the higher Br concentrations.

A new $\mathrm{Br}$ calibration curve was prepared each time new stock solutions of $\mathrm{KBr}$ or the other reagents were prepared as some slight variation (less than $1.5 \%$ ) was found in the absorbance with some batches of new stock solutions.

Care must be taken that the absorbance spectra are completed within 15 minutes of adding the chloramine $\mathrm{T}$ as the excess $\mathrm{Cl}_{2}$ will in chloroform, combine with $\mathrm{Br}_{2}$ to form the yellow $\mathrm{Cl}-\mathrm{Br}$, with the resultant change in absorbance. 
Table 1

Relationship between bromine concentration and absorbance in chloroform

\begin{tabular}{|ccc|}
\hline $\begin{array}{c}\text { Concentration } \\
\text { of KBr solution }(\%)\end{array}$ & Bromine $(\mathrm{g} / \mathrm{l})$ & Abs.400 nm-Abs.650 $\mathrm{nm}$ \\
\hline 0.0750 & 0.5036 & 1.490 \\
0.0625 & 0.4197 & 1.310 \\
0.0500 & 0.3357 & 1.135 \\
0.0375 & 0.2518 & 0.910 \\
0.0250 & 0.1679 & 0.690 \\
0.0125 & 0.0839 & 0.339 \\
0.00 & 0.000 & 0.00 \\
\hline
\end{tabular}

\section{Presence of iodine}

In chloroform, iodine forms a purple solution whose absorbance spectrum shows a single maximum at $480-505 \mathrm{~nm}$. At $400 \mathrm{~nm}$ however, there is no absorbance due to iodine (see difference spectrum in Fig. 1). Bromine forms a brown solution in chloroform with a fairly broad maximum at $410 \mathrm{~nm}$. At $410 \mathrm{~nm}$, iodine still shows a little absorbance but as bromine absorbance is still near its maximum at $400 \mathrm{~nm}$, this wavelength is used in bromine determinations as it excludes any absorbance due to iodine.

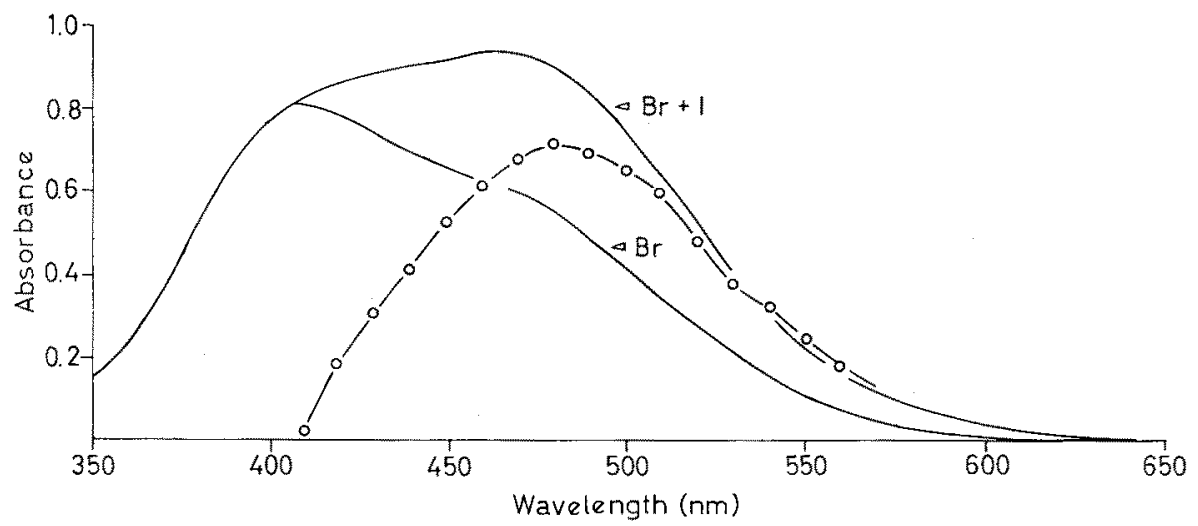

Fig. 1: Absorbance spectra of bromine in chloroform with and without iodine; $0=$ difference spectrum of the two solutions (absorbance scale expanded $\times 2$ ), showing the typical iodine maximum at $480 \mathrm{~nm}$

A number of calibration solutions, containing both bromine and iodine, were prepared with concentrations ranging from $0.0-0.335 \mathrm{~g} / 1$ and $0.0-0.382 \mathrm{~g} / 1 \mathrm{respec}-$ tively. Where iodine was present, the absorbance maximum of bromine was broadened but the absorbance at $400 \mathrm{~nm}$ remained proportional to the bromine concentration as previously found with the $\mathrm{KBr}$ solutions. Thus although some iodine may be similtaneously liberated with the bromine, it does not interfere with the absorbance of the latter while measured at $400 \mathrm{~nm}$. 


\section{Volatilization of bromine during ashing}

Recovery of bromine after ashing known amounts of bromine (as $\mathrm{KBr}$ or $\alpha$ bromnaphthalin) was complete, showing that the addition of $10.0 \mathrm{ml}$ of $10 \% \mathrm{Na}_{2} \mathrm{CO}_{3}$ is sufficient to prevent any volatilization of bromine at the ashing temperature. Generally, $10.0 \mathrm{ml}$ of $\mathrm{Na}_{2} \mathrm{CO}_{3}$ solution was added for every $3 \mathrm{~g}$ of algal powder to be ashed.

\section{Bromine content of seawater and marine Rhodophyta}

Knowing the volume and density of seawater used, it is a simple calculation to express bromine content in ppm (parts per million by weight). Values obtained at a number of stations are given in Table 2.

Table 2

Bromine concentrations at a number of stations in the Cape Province, South Africa

\begin{tabular}{|llccc|}
\hline Locality & Situation & Date & ppm Br & $\begin{array}{c}\text { No. of } \\
\text { replicates }\end{array}$ \\
\hline Riet River & open water & 10. 12. 1970 & 66.5 & 2 \\
& littoral rockpool & 10. 12. 1970 & 66.1 & 2 \\
Kowie River & littoral rockpool & 12.4 .1970 & 69.6 & 2 \\
Kleinemond & open estuary & 15.4 .1970 & 67.9 & 2 \\
River & closed estuary & 15.4 .1970 & 45.7 & 2 \\
\hline
\end{tabular}

Similarly by using known weights of the dried algal powder for ashing and knowing the volume of the final sample solution, the percentage of bromine in the dry weight of the alga is calculated. A number of marine Rhodophyta were tested by this method and the results are given in Table 3.

Table 3

$\% \mathrm{Br} / \mathrm{dry}$ weight of several marine Rhodophyta from Southern Africa (collected December/January 1970/71)

\begin{tabular}{|c|c|c|c|}
\hline Species & Locality & $\begin{array}{c}0 / 0 \mathrm{Br} / \mathrm{dry} \\
\text { weight }\end{array}$ & $\begin{array}{l}\text { No. of } \\
\text { replicates }\end{array}$ \\
\hline $\begin{array}{l}\text { Calliblepharis fimbriata } \\
\text { (C. Ag.) KuETZING }\end{array}$ & Riet River & 0.164 & 1 \\
\hline $\begin{array}{l}\text { Chondrococcus hornemanni } \\
\text { (MERT.) SCHMITZ }\end{array}$ & Riet River & 1.45 & 1 \\
\hline Gelidium pristoides (Turn.) Kuetzing & Riet River & $0.084-0.105$ & 3 \\
\hline $\begin{array}{l}\text { Gigartina insignis } \\
\text { (EndL. \& Dies.) Schmitz }\end{array}$ & Riet River & 0.082 & 1 \\
\hline Gracilaria beckeri (J. AG.) PaPENFuss & Riet River & 0.095 & 1 \\
\hline Kuetzingia natalensis J. AG. & Inhaca Island & $1.00-1.23$ & 3 \\
\hline Porphyra capensis KUETZING & Riet River & 0.039 & 1 \\
\hline Pterosiphonia cloiopbylla (C. AG.) & Riet River & $5.81-5.86$ & 4 \\
\hline $\begin{array}{l}\text { FALKENBERG } \\
\text { Vidalia fimbriata (R. BR.) J. AG. }\end{array}$ & Inhaca Island & $2.22-2.57$ & 2 \\
\hline
\end{tabular}




\section{DISCUSSION}

The method described is a convenient and accurate modification of that of SEGI \& TAKATORI (1952) and as only the wavelength of maximum bromine absorbance is used, it increases the specificity of the determination. Other halogens do not interfere in the bromine determinations, and consistent results can be obtained for bromine over a large concentration range.

Bromine is represented in seawater in concentrations of approximately $66 \mathrm{ppm}$ (HAsLAm \& Gibson 1950), but has been found in much higher concentrations in the thalli of some red algae (VINOGRADOv 1953). Variation in the bromine content of seawater reported here (Table 2) is probably due to dilution and evaporation especially in the small, littoral rockpools. The closed Kleinemond Estuary is substantially diluted with freshwater $(10.7 \mathrm{ppm} \mathrm{Br})$ and the high bromine content of the Kleinemond River itself may be due to some residual methyl bromide, used as a nematocide in the pineapple plantations along its banks.

Within the Rhodophyta, the Rhodomelaceae appear to be particularly rich in bromine (AugIER 1953), and up to $6 \% \mathrm{Br} /$ dry weight has been reported in Odonthalia corymbifera (ToKIDA 1954). In the present study, only Chondrococcus, Kuetzingia, Pterosiphonia and Vidalia contain over $1 \% \mathrm{Br} / \mathrm{dry}$ weight, and of these genera only Chondrococcus is not a member of the Rhodomelaceae. Although present in considerable amounts, bromine does not seem to play an essential part in the metabolism of the members of the Rhodomelaceae so far studied (Fries 1966).

\section{SUMMARY}

1. A simple spectrophotometric method is described for the determination of bromine in organic material in the presence of other halogens.

2. The absorbance at $400 \mathrm{~nm}$ in chloroform is proportional to the bromine concentration between 0 and $0.6 \mathrm{~g} / 1$, although standards should be run with each set of determinations.

3. The results of a number of bromine determinations on seawater and the ash of several marine Rhodophyta are presented and discussed.

Acknowledgements. I am indebted to Mr. D. Hasses of the Pineapple Research Unit for helpful discussions and to Professor E. S. TwYMAN for critical reading of the manuscript.

\section{LITERATURE CITED}

Avgrer, J., 1953. La constitution chimique de quelques Floridees Rhodomelacees. Revue gén. Bot. 60, 257-283.

Balard, A. J., 1826. Memoires sur une substance particuliere contenue dans l'eau de la mer (le brome). Annls Chim. Phys. 2, 337.

Berkovich, M. T. \& Luzina, G. S., 1950. Colorimetric determination of small amounts of bromine in air. Zav. Lab. 16, 1399-1400. 
BINKLEY, F., 1948. Colorimetric reaction of the chloride ion. J. biol. Chem. 173, 403-405.

FrIES, L., 1966. Influence of iodine and bromine on growth of some red algae in axenic culture. Physiologia Pl. 19, 800-808.

Haslam, J. \& Grbson, R. O., 1950. The analytical chemistry of bromine manufacture. III. Survey of the in-shore waters round the coast of Great Britain. Analyst, Lond. 75, 357-370.

Hunter, G. \& Goldspink, A. A., 1954. Microdetermination of bromide in presence of chloride. Analyst, Lond. 79, 467-475.

InDovina, R., 1935. The determination of bromine in blood. Biochem. Z. 275, 286-292.

Pincussen, L. \& Roman, W., 1929. Studies on methods. IX. Combined determination of halogens in organic substances. Biochem. Z. 207, 416-425.

SEGI, T, \& TAKATORI, K,, 1952. Colorimetric determination of bromine in the marine algae. Rep. Fac. Fish., prefect. Univ. Mie, 1, 209-214.

Shirahama, K., Sasa \& Uno, T., 1944. On the brom contents of seaweeds. Bull. Jap. Soc. scient. Fish. 12, 224-231.

TokidA, J., 1954. The marine algae of southern Saghalien. Mem. Fac. Fish., Hokkaido Univ. $2,1-264$.

Vinogradov, A. P., 1953. The elementary chemical composition of marine organisms. Mem. Sears Fdn mar. Res. 2, 1-647.

Author's address: Dr. P. SAENGER

Rhodes University

Department of Botany and Microbiology

Grahamstown

South Africa 